\title{
Burnout Knowledge of Female Nurses during the COVID-19 Pandemic: Study at dr. Agoesdjam Hospital in Ketapang Regency, Indonesia
}

DOI: https://doi.org/10.47175/rissj.v2i4.330

\author{
| Arkanudin $^{1, *} \mid$ Rupita $^{2}$ | \\ ${ }^{1}$ Deparment of Anthropology, \\ Faculty of Social and Political \\ Sciences, Universitas \\ Tanjungpura Pontianak, \\ Indonesia \\ ${ }^{2}$ Deparment of Sociology, \\ Faculty of Social and Political \\ Sciences, Universitas \\ Tanjungpura Pontianak, \\ Indonesia \\ *arkanudin@fisip.untan.ac.id
}

\begin{abstract}
The COVID-19 pandemic has hit Indonesia where the worrying situation has affected almost every all-region in Indonesia, including West Kalimantan. One of the referral hospitals for the case of COVID-19 in West Kalimantan is RSUD dr. Agoesdjam is the only one referral hospital in the Ketapang Regency area. This makes a critical situation, considering that Ketapang Regency is very large and there is only one referral hospital. The problem that arises later is the number of patients from various regions who come to check themselves at RSUD dr. Agoesdjam Ketapang, where this hospital has a limited number of doctors and health workers. This causes job burnout for health workers, where they have to work extra in monitoring and handling patients regularly in their work environment. This study uses a descriptive qualitative approach with an exploration of primary and secondary data. Primary data refers to the interview results while secondary data comes from journal searches and online media coverage. Based on the results and discussion in this study, it can be concluded that the COVID-19 situation in RSUD dr. Agoesdjam is quite worrying so that it increases the alertness of the hospital, in this case, the job burnout of health workers is increasing. The duties and responsibilities of nurses are a priority in handling COVID-19 patients and this case raises fear, worry, and energy burden and thoughts for health workers, especially nurses at RSUD dr. Agoesdjam Ketapang. Furthermore, the job burnout experienced by nurses in dealing with the COVID-19 situation is work overload, poor performance, fatigue, and reduced alertness because they are overshadowed by anxiety and worry. KEYWORDS

job burnout; referral hospitals for the case of COVID-19; health workers; RSUD dr. Agoesdjam Ketapang; Ketapang Regency
\end{abstract}

\section{INTRODUCTION}

The outbreak of COVID-19 became a tragic event that occurred in Wuhan, China, and then it is continuing to spread around the world. Indonesia is one of the countries affected by COVID-19, where current data shows the number of positive patients infected coronavirus (COVID-19) is 7,418 cases, with 635 deaths and 913 recovered (COVID-19 Response Acceleration Task Force, 2020).

There has been an alarming rise in COVID cases in several areas in Indonesia, including West Kalimantan. Since the first case of COVID-19 was discovered until April 2020, there have been 31 positive cases of COVID-19 in West Kalimantan. The spread of positive patients in several districts/cities. One of them is in Ketapang Regency, where RSUD dr. 
Agoesdjam is the only one referral hospital for the case of COVID-19 in the Ketapang Regency.

The situation for handling COVID-19 in the West Kalimantan region is carried out based on the Governor Regulation of West Kalimantan Province Number 110 of 2020, concerning the application of discipline and law enforcement of health protocols as an effort to prevent and control the COVID-19. Even in some areas, the community has independently mobilized strength against COVID-19 with existing local social capital (Rupita, 2021; Niko, 2021; Musa et al., 2021).

The problem that arises later is the number of patients from various regions who come to check themselves at RSUD dr. Agoesdjam Ketapang, where this hospital has a limited number of doctors and health workers. This causes job burnout for health workers, where they have to work extra in monitoring and handling patients regularly in their work environment.

The work environment refers to the things that surround the work of employees in the office or organization. The conditions of the workplace environment and atmosphere are created by the leader. In this case, the work environment refers to the dr. Agoesdjam Ketapang. Working with very tight deadlines, under supervision and pressure will lead to burnout. This can affect a person's performance in delivering high-quality work.

Burnout is a fairly new phenomenon in the field of psychology. This understanding of the burnout concept has existed for a long time, but in 1974 the problem of burnout was only the subject of study by psychologists. The term burnout was first introduced by Herbert Freudenberger. Freudenberger is a clinical psychologist who worked with troubled adolescents at a New York service agency. He observed changes in the behavior of volunteers who had worked for many years. According to him, the volunteers experienced mental fatigue, lost commitment, and decreased motivation over time.

According to Freudenberger (in Farber, 1991) burnout is a form of fatigue caused by someone working too much, dedicated and highly committed, seeing their needs and desires as second things. This causes them to feel pressured to give more.

This pressure can come from within oneself, from clients and administrators or supervisors. These pressures create a sense of guilt which ultimately prompts them to add more energy. Then, added to the traditions in the local communities of each region regarding the division of gender work, in this situation women are the parties who often get a double burden (Niko, 2018; Niko, 2020).

One of the factors that can affect nursing services is burnout syndrome. Burnout syndrome experienced by nurses is a condition when nurses show behaviors such as giving unpleasant responses to patients, delaying work, getting angry easily when co-workers or patients ask simple things, complaining of being tired and dizzy, and worse, not caring about work and the surrounding circumstances. (Asih \& Trisni, 2015).

When the reality that occurs does not support their idealism, they will continue to strive to achieve these ideals and resources will eventually run out, so they experience burnout due to delay in achieving expectations. Since then the terminology of burnout has developed into a broad sense and is used to understand a person's psychological phenomena.

Female nurses are required to have a healthy work-life balance. Balance their role in the family as mothers, wives, as well as domestic workers, and on the other hand, women also work as nurses in hospitals who are required to be professional as nurses (Rupita, 2020). In the workplace, burnout is a term used related to job stress. Burnout is a situation where employees suffer from chronic fatigue, boredom, depression, and withdrawal behaviors in the workplace. 
The context of this research is burnout on female nurses in RSUD dr. Agoesdjam Ketapang. Nurses often meet patients with various characters and illnesses. Not only from the patient's side, which can make nurses experience physical, emotional, and mental exhaustion but from the patient's demanding family, co-workers who are not in line, and doctors who tend to be arrogant (Mariyanti, 2011). Based on the description above, this study focuses more on how far the knowledge of female nurses in RSUD dr. Agoesdjam Ketapang regarding burnout during their performance and integrity services during the current COVID-19 pandemic.

\section{RESEARCH METHODS}

This study uses a descriptive qualitative approach with an exploration of primary and secondary data. Primary data refers to the interview results while secondary data comes from journal searches and online media coverage. The informants in this study were female nurses at RSUD dr. Agoesdjam Ketapang was conducted by purposive sampling technique. Our technical interviews were conducted online, considering the COVID-19 pandemic which makes it impossible to meet face-to-face, especially when they work in the hospital.

There were 5 informants, consisting of 1 female nurse who works in the COVID-19 unit and 4 female nurses in the inpatient and emergency room. The selection of informants was based on the knowledge of the informants in carrying out their duties as the front line in RSUD dr. Agoesdjam Ketapang Regency.

Table 1. The Characteristics of Informants

\begin{tabular}{ccccl}
\hline No. & $\begin{array}{c}\text { Informant's } \\
\text { Initials }\end{array}$ & Age & Gender & \multicolumn{1}{c}{ Education } \\
\hline $\mathbf{1 .}$ & QA & 29 & Women & Diploma-Three D3 \\
$\mathbf{2 .}$ & OP & 30 & Women & Diploma-Three D3 \\
$\mathbf{3 .}$ & HE & 42 & Women & Diploma-Three D3 \\
$\mathbf{4 .}$ & RY & 45 & Women & Bachelor Degree \\
$\mathbf{5 .}$ & TR & 33 & Women & Bachelor Degree \\
\hline
\end{tabular}

\section{RESULTS AND DISCUSSION}

The most visible impact of burnout is the decline in performance and service quality. Individuals who experience burnout syndrome will lose the meaning of the work they do because of a prolonged response to the emotional, physical and mental exhaustion they experience. Nurses are required to understand their patients, give attention, focus, and be warm to patients.

In the COVID-19 isolation room at the RSUD dr Agoesdjam Ketapang, nurses can get patients of various age groups with different patient characteristics. This affects the patient's desire for service and the demands on nurses to perform various tasks.

The more demands for nurses make nurses are experiencing higher workloads in providing safe and effective nursing practices and working in an environment that has high clinical standards. Excessive physical and mental workload causes work-related stress. The impact of excessive workload will experience work fatigue (Triwijayanti, 2015; Triwijayanti, 2016).

Workers who experience burnout will tend to be silent and look helpless, this happens because of a loss of motivation and enthusiasm which results in helplessness. Under stressful conditions, workers tend to be more active and emotionally aggressive. Burnout and stress sufferers both experience problems, especially at work, but the response is 
different. Prolonged stress can potentially lead to burnout, while burnout conditions experienced by workers are not necessarily caused by stress.

Nurses on duty in the inpatient room at RSUD dr Agoedjam Ketapang work divided into three shifts, eight hours for the morning shift, eight hours for the afternoon shift, and eight hours for the night shift. The duties of nurses agreed in the 1983 workshop based on the function of nurses in providing nursing care are as follows: assessing patient needs, planning nursing actions, implementing nursing plans, evaluating nursing care results, documenting the nursing process (Hidayat, 2009).

Lumenta (1989) asserts that the main tasks of nurses are paying attention to patient needs, caring for patients with full responsibility, and providing care services to individuals or groups of people who are under stress due to illness. Nurses on duty in the inpatient room very often meet patients with various characters and illnesses. Patients often complain about their illness, this makes nurses experience fatigue.

The stress reaction that is especially common in people with high standards is burnout. Burnout is a state of emotional and physical exhaustion, low productivity, and feelings of isolation, often caused by work-related stress. This was disclosed by the informant as follows:

"We must be tired. Especially in the midst of this pandemic situation, as nurses, we have to work extra for the patients. It is not only patients who has tested positive for COVID19, but also other patients who must be taken care of to avoid the transmission of this virus, right." (Interview with informant 3 ).

People who face high-pressure conditions daily often feel weak, hopeless, and emotionally drained and may eventually stop trying (Lefton, 1997). Burnout is a state of psychological pressure on an employee after being in the job for a certain time. This was stated by the informant, as follows:

"Yes ma'am. Now it's been two months since the COVID-19 pandemic. Quite draining energy and mind too. On the one hand, nurses are the front line in the hospital, right? We feel fear that when we go home we will not be sterile. It is known that this hospital is the most vulnerable place for the transmission of this virus." (Interview Results, informant 2)

"Tired. However, our duty as nurses so we live it as a calling for life. So, tired or afraid that has been fought with courage. Having an emotionally unstable, not only draining energy. We are afraid, we are also tired of dealing with situations. But we must face it." (Interview, Informant 1)

Emotional exhaustion is a feeling of being emotionally overwhelmed due to excessive workload and personal conflict. Emotional exhaustion is a chronic state of physical and emotional depletion characterized by a lack of energy such as losing enthusiasm and motivation to carry out activities. This is felt by the informant, the following are the results of the interview:

"I do not think it is because of the heavy burden. It is because our situation that working as usual, even though there is overtime under strict supervision of COVID-19 patients, right. But what makes us emotionally drained is our thoughts and fears that do not always come close. We know that many health workers in Indonesia have died because of this pandemic situation. So we just pray for the best for our lives." (Interview, Informant 4) 
Depersonalization is the development of cynical and callous feelings towards others (Spector, 1996). The process of balancing the job demands and individual abilities. This is in the form of a cynical attitude towards people who are in the scope of work and a tendency to withdraw and reduce involvement in work. This is said by the informant as follows:

"We understand very well that our job desk as nurses is very vulnerable in this pandemic situation. We also see that there is ostracism everywhere and even nurses who have been expelled because they are considered to be spreaders of COVID-19. This is very disturbing our work performance because there is a cynical attitude of society. As if we are spreading the virus from hospital to home." (Interview, Informant 5)

This behavior is shown as an effort to protect themselves from a feeling of dissatisfaction because sufferers assume that by behaving like that, they will be safe and avoid uncertainty at work.

Burnout arises from prolonged stress, so many factors that influence burnout are often associated with stress (Widiastuti and Kamsih, 2008). Low personal accomplishment where individuals are never satisfied with the results of their work feels they have never done anything useful for themselves or others. This was stated by the following informants:

" Low personal accomplishment happens to us because we are stressed thinking about these patients who have tested positive for COVID-19, then there are also many cynical people in the neighborhood, this adds to the burden on our minds which indirectly affects our work performance. However, I really consciously surrendering to the power of Almighty God." (Interview, Informant 1)

In addition, the COVID-19 hospitalization provided by the local government at the RSUD dr. Agoesdjam Ketapang, there is also outpatient treatment in hospital services, where reactive patients can self-isolate under the supervision of health workers from dr. Agoesdjam. In contrast to inpatient care, ambulatory services are a form of simple medical services. Outpatient services are medical services provided to patients, not in the form of hospitalization (Feste, 2000 in Nurhayati, 2004).

The task of the nurse on duty in the outpatient room is to help doctors prepare tools, weigh, check the patient's blood pressure, and give any medicines that are needed. During this COVID-19 period, a COVID-19 PCR test is also provided. Nurses work on orders or doctor's instructions.

In outpatient services for patients who are reactive when testing for COVID-19, the frequency of meetings between nurses and patients is shorter when compared to nurses who work in inpatient rooms. Nurses in the outpatient ward meet with patients only on the day of the examination, but nurses more often meet with doctors who examine patients. Problems often experienced by nurses in outpatient rooms are complaints from patients about slow service, administrative performance, nurses who act "bitty", doctors who do not take their work seriously, and specialist doctors who come late to the hospital and leave early.

Bernadin (in Rosyid, 1996) describes burnout as a condition that reflects an emotional reaction to people who work in the field of human services and work closely with the community. Burnout sufferers are often found in nurses in hospitals, social workers, teachers, and members of the police. According to Cherniss (1980), burnout is a 
psychological withdrawal from work done as a reaction to stress and dissatisfaction with excessive or prolonged work situations.

Based on the fact that the nurses on duty in the COVID-19 inpatient room and the COVID-19 outpatient at the RSUD dr. Agoesdjam Ketapang has the potential to experience stress/pressure due to work overload demands related to other people, such as providing nursing services to patients, both for healing or recovering their physical and mental status, providing other services for patient comfort and safety such as bed arrangement, performing administrative tasks, providing nursing education, conducting various researches and actively participating in the education of prospective nurses. This situation, if it continues, will cause nurses to experience physical, emotional, and mental fatigue, which is known as burnout symptoms.

\section{CONCLUSION}

Based on the results and discussion in this study, it can be concluded that the COVID-19 situation in RSUD dr. Agoesdjam is quite worrying so that it increases the alertness of the hospital. In this case, burnout has increased significantly. The duties and responsibilities of nurses are a priority in handling COVID-19 patients which in this case raises fear, worry, and a burden of energy and thoughts for health workers, especially nurses at RSUD dr. Agoesdjam Ketapang. Furthermore, the burnout experienced by nurses in dealing with the COVID-19 situation is that there is work overload, poor work performance due to fatigue because they are overshadowed by anxiety and worry. The suggestions that we can put are: 1) the local government of Ketapang Regency consistently provides local incentives for health workers; 2) a policy to add a health team, either with a regional contract or volunteer scheme.

\section{REFERENCES}

Asih, F., \& Trisni, L. (2015). Hubungan Antara Kepribadian Hardiness dengan Burnout pada Perawat Gawat Darurat di Rumah Sakit Pantiwilasa Citarum. Psikodimensia: Kajian Ilmiah Psikologi. Vol. 14, No. 1, 11-23. Doi: https://doi.org/10.24167/psiko.v14i1.370

Cherniss, C. (1980). Staff Burnout: Job Stress in the Human Services. London: Sage Publication.

Farber, A.B. (1991). Crisis in Education: Stress and Burnout in the American Teacher. San Fransisco: Bass Publisher.

Hidayat A. A. (2008). Metode Penelitian Kebidanan dan Teknik Analisa Data. Jakarta: Salemba Medika.

Lefton, L. A. (1997). Psychology sixty edition. America: Allyn \& Bacon.

Lumenta, B. (1989). Pelayanan Medik Care Konflik dan Harapan, Tinjauan Fenomena Sosial. Yogyakarta: Kanisius.

Musa, P., Suryadi, A., \& Paramitha, R. R. (2021). Kerentanan Sosial dan Ekonomi Masyarakat di Perbatasan Kabupaten Sambas Menghadapi Pandemi COVID-19. Jurnal Muara: Ilmu Sosial, Humaniora dan Seni. 5(1):180-188. Doi: 10.24912/jmishumsen.v5i1.10032.2021

Niko, N. (2018). Perempuan Dayak Benawan: Kedudukan pada Struktur Domestik dan Publik. Yogyakarta: Deepublish.

Niko, N. (2020). Gender Struggle: What Can We Learn from the Dayak Benawan Women? Walailak Journal of Social Science. 13(2): 269-292. Retrieved from: https://so06.tci-thaijo.org/index.php/wjss/article/view/234156 
Niko, N. (2021). Poor and Hunger: How do Indigenous Peoples' Respond to COVID-19 in Indonesia. Journal of Community Development Research (Humanities and Social Sciences). 14(1) 81-92. Doi: https://doi.org/10.14456/jcdr-hs.2021.8

Nurhayati, E. (2004). Tinjauan Karakteristik Pasien Jaminan Pemeliharaan Kesehatan Masyarakat (JPKM) Pensiun di Unit Rawat Jalan Rumah Sakit Pelabuhan. Jakarta: Fakultas Kesehatan dan Fisioterapi Universitas Esa Unggul.

Peraturan Gubernur (PERGUB) Provinsi Kalimantan Barat Nomor 110 Tahun 2020, tentang Penerapan Disiplin Dan Penegakan Hukum Protokol Kesehatan Sebagai Upaya Pencegahan Dan Pengendalian Corona Virus Disease 2019. Retrieved from: https://peraturan.bpk.go.id/Home/Details/145352/pergub-prov-kalimantan-barat-no110-tahun-202

Rosyid, H. F. (1996). Burnout: Penghambat Produktifitas yang Perlu dicermati. Buletin Psikologi. Tahun IV, No. 1, 19-25.

Rupita. (2020). Konflik Peran Perawat Perempuan pada RSUD dr. Agoesdjam Kabupaten Ketapang Kalimantan Barat. Nuansa: Jurnal Penelitian Ilmu Sosial dan Keagamaan Islam. 17(1): 32-45. Doi: https://doi.org/10.19105/nuansa.v17i1.3013

Rupita. (2021). Pemanfaatan Modal Sosial Lokal dalam Menghadapi Pandemi COVID-19. Jurnal Neo Societal. 6(1) 46-55.

Spector, P. E. (2008). Industrial and Organizational Psychology. USA: John Wiley and Sons Inc.

Triwijaya, R. (2015). Caring Dimensions Inventory Dalam Tatanan Pelayanan Keperawatan. Jurnal Manajemen Keperawatan. Vol. 3, No. 1, 42-47.

Triwijayanti, R. (2016). Hubungan Locus of control Dengan Burnout Perawat Di Ruang Rawat Inap Rumah Sakit Muhammadiyah Palembang. Master Thesis, Universitas Diponegoro.

Widiastuti, D. Z., \& Kamsih, A. (2008). Hubungan Antara Kepribadian Hardiness Dengan Burnout Pada Guru Sekolah Dasar. Jurnal InSight. Vol. 6, No. 2. 